\title{
God kreftbehandling krever riktig ernæring
}

Godt kosthold kan bidra til at kreftpasienter tåler behandlingen bedre, får økt livskvalitet og lever lenger . Pasientens ernæringsbehov bør derfor kartlegges tidlig i behandlingen.

\section{Forfattere}

\section{Caroline Breivik}

Sykepleier

Kreftsenteret, Oslo universitetssykehus Ullevål

\section{Mari Arnøy Slåttum}

Spesialrådgiver

Kreftforeningen

\section{Anne Lise Ryel}

Generalsekretær Kreftforeningen

\section{Ingvild Paur}

Prosjektleder

Nasjonal kompetansetjeneste for sykdomsrelatert underernæring,Oslo universitetssykehus

\section{Nøkkelord}

Underernæring Ernæring Kreft

Sykepleien 2018 106(65134)(e-65134)

DOI: https://doi.org/10.4220/Sykepleiens.2018.65134

\section{HOVEDBUDSKAP}

Det har i løpet av de siste tiårene skjedd mye innenfor ernæringsarbeid i helse- og omsorgstjenesten, og nye føringer for god ernæringspraksis har ført til strukturelle endringer i arbeidsdagen til helsepersonell. Hvorfor skal dette målrettede arbeidet prioriteres? For kreftpasienten kan tidlig og målrettet identifisering og behandling av ernæringsproblematikk bidra til bedre toleranse av behandling, økt livskvalitet og funksjonsstatus, og forlenget overlevelse. 
Det har de siste tiårene skjedd mye innen ernæringsarbeid i helse- og omsorgstjenesten, og nye føringer for god ernæringspraksis har ført til endringer i arbeidsdagen til helsepersonell. Hvorfor skal dette målrettete arbeidet prioriteres? For kreftpasienten kan tidlig og målrettet identifisering og behandling av ernæringsproblematikk bidra til bedre toleranse av behandling, økt livskvalitet og funksjonsstatus, og forlenget overlevelse.

Kreftpasienter har en særlig høy risiko for vekttap og underernæring fordi både kreften i seg selv, kreftbehandlingen og følelsesmessige og psykologiske påkjenninger hos pasienten kan bidra til økte behov og endret næringsinntak (1-4). Eldre kreftpasienter er i ytterligere risiko da normal aldring, inkludert sensoriske, fysiske og psykososiale endringer, kan ha en negativ påvirkning på ernæringstilstand (5).

\section{三 «Nok og riktig mat vil ha stor betydning for pasienten.»}

Vekttap og underernæring hos kreftpasienter kan innebære mange og store negative konsekvenser, som blant annet nedsatt immunforsvar, forsinket sårheling, redusert behandlingseffekt, lengre sykehusopphold og forkortet overlevelse (3). Vi vet også at underernæring kan føre til redusert kjemoterapidose og økt fare for toksisitet (6-9), og kan dermed hindre eller utelukke kreftbehandling (10). Det er således ikke vanskelig å forstå at nok og riktig mat vil ha stor betydning for pasienten, men hvordan vet vi hvem som har nytte av ernæringsbehandling?

\section{Hvem er risikopasienten?}


I mange tilfeller er det ikke åpenbart verken for helsepersonell, pårørende eller pasienten selv om vedkommende er underernært eller i risiko for å bli underernært. Verken observasjon, klinisk blikk eller bruk av enkle antropometriske mål som vekt og BMI alene, vil fange opp alle som har nytte av ernæringsbehandling.

Fra Kreftsenteret på Ullevål sykehus finner vi flere eksempler på tilfeller hvor bedømmelse av ernæringsstatus er en utfordring. Et eksempel kan være pasienter med ødemer eller annen væskeansamling som acites, og pasienter som tilføres store mengder væske. Disse kan være i ernæringsmessig risiko eller underernært uten at dette fanges opp ved vektutvikling, BMI eller klinisk blikk alene.

En annen vanlig utfordring er pasienter som ved innkomst sier at de spiser godt, men hvor man ikke kan være sikker på hva dette betyr i forhold til behov. Dette er særlig aktuelt hos eldre pasienter med redusert sultfølelse, og pasienter med kognitiv svikt. I disse tilfellene er en kostregistrering nødvendig for å kunne vurdere inntak opp mot behov.

En tredje gruppe der det kan være vanskelig å bedømme ernæringsstatus, er pasienter med overvekt og fedme. Mange kreftpasienter er overvektige på diagnosetidspunktet, og tradisjonelt har det vært antatt at disse pasientene er velernærte. Som en konsekvens har vurdering av ernæringsmessig status sjeldent vært utført for denne pasientgruppen. Nyere studier har imidlertid funnet at overvektige også kan være underernærte (11). Overvekt og fedme kan altså kamuflere en pasients sviktende ernæringsstatus som igjen kan ha betydning innen rehabilitering og toleranse for behandlingen.

\section{三 «Nyere studier har imidlertid funnet at overvektige også kan være underernærte.»}


Derfor er vurdering av ernæringsmessig risiko hos alle pasienter et sentralt førstesteg i både forebygging og behandling av underernæring. Tidlig innsats er både enklere og mindre ressurskrevende enn behandling av langtkommet og alvorlig underernæring.

Ved å fange opp ernæringsmessig risiko tidligst mulig kan man bidra til at ernæringsbehandling kan igangsettes før underernæring har oppstått. Per i dag anbefaler Helsedirektoratet fem ulike skjema for vurdering av ernæringsstatus, og det er opp til den enkelte institusjon å velge ett (12). Det er imidlertid satt ned en arbeidsgruppe som skal se på om det er hensiktsmessig å anbefale ett skjema per omsorgsnivå (sykehus, sykehjem, hjemmetjeneste) og dette arbeidet er forventet klart mot slutten av 2018.

\section{Hva med tiltakene?}

I fokuset på vurdering og kartlegging er det likevel viktig å huske på at det er risikovurderingens påfølgende tiltak, og monitorering av disse, som kan forbedre pasientens ernæringsstatus. Dette er særlig viktig å huske på at en kostregistrering alene ikke vil få pasienten til å spise mer. Dessverre viser erfaringer at kostregistrering ofte iverksettes og viser for lavt inntak, men at følgetiltakene uteblir. Tall fra nutritionDay viste at hele 60 prosent av de underernærte pasientene ikke fikk den behandlingen de hadde behov for (13).

Hvilke ernæringsmessige tiltak som skal igangsettes vil være situasjonsavhengig og basert på den enkelte pasients preferanser, medisinske historie og respons på behandling (2). Tiltak bør likevel være basert på risikovurdering, individuell kartlegging, sikre nok og riktig næring og overføring av informasjon.

\section{三 «Hvilke ernæringsmessige tiltak som skal igangsettes vil være situasjonsavhengig.»}


Gjennom innføringen av

pasientsikkerhetsprogrammets tiltakspakker for

forebygging og behandling av underernæring vil det

bli mye fokus på dette temaet i sykehus, sykehjem og i

hjemmetjenesten i 2018. Det er bygget opp mye erfaringer gjennom pilotprosjektene som

forhåpentligvis kan brukes videre (14). Erfaringer fra

Kreftsenteret på Ullevål sykehus viser at denne

implementering har gitt økt fokus på å starte tiltak

tidligere enn før, og at jevnlig internundervisning og

korte påminnelser påvirker til utførelse av flere tiltak

enn tidligere.

Konkrete tiltak for å fremme god arbeidsflyt for helsepersonell innen ernæringsarbeidet kan være å bruke fraser i kartleggingsnotat med resultater fra tidligere innleggelser. Ved Kreftklinikken på Ullevål har de god erfaring med dette ved at de sparer tid ved senere innleggelser. I tillegg danner de seg raskt inntrykk om eventuelle tiltak har hatt effekt, eller om pasienten stadig taper vekt. De har også hatt god nytte av å sikre at tiltak kommer frem både i kartleggingsnotatet under risikovurderingen og i behandlingsplanen.

\section{Grunnleggende behov}

I en hverdag der media og forskning domineres av både kompleks og også motstridende informasjon om ernæringsbehandling av kreftpasienter, er det viktig at behandler alltid tar tak i pasientens grunnleggende behov først. En pasient som er i underskudd på energi og protein vil alltid gå i retning av en forverret ernæringsstatus. Derfor er det avgjørende å sørge for et tilstrekkelig inntak av energi og protein.

\section{三 «En pasient som er i underskudd på energi og protein vil alltid gå i retning av en forverret ernæringsstatus.»}


Etterlevelse av tiltak fra pasientens side er viktig. Det er vesentlig at pasientene selv får eierskap til problemstillingen ved at de får kjennskap om viktigheten av ernæring som en del av kreftbehandlingen, og blir tilstrekkelig informert og involvert. I en serie studier av tarmkreftpasienter i Portugal viste forskerne at pasienter som ble anbefalt et individtilpasset kosthold basert på vanlig mat, hadde bedre overlevelse og mindre toksisitet enn pasienter som enten fikk standard næringsdrikk i tillegg til vanlig mat eller som fortsatte med sitt vanlige kosthold (15). Pasientene på individtilpasset ernæringsbehandling med vanlig mat opprettholdt også i større grad ernæringsstatus (16).

\section{Eierskap til behandlingen}

Det ligger en mulighet til forbedring av ernæringsarbeid med mer målrettet og strukturert arbeid (17). Med ernæring som en integrert del av pasientsikkerhetsprogrammet legges det opp til at man kan skape gode og faste rutiner i arbeidet med å både forebygge og behandle underernæring. Vi har nå således en mulighet å løfte ernæringens betydning i pasientbehandlingen. Om vi som helsepersonell også føler et eierskap til ernæringsbehandlingen, på lik linje med eierskap til resten av kreftbehandlingen, vil forbedringsmulighetene styrkes ytterligere. Dette vil også kunne bidra til at hver enkelt pasient har best mulig forutsetninger for å kunne gjennomføre og tåle sin kreftbehandling.

\section{Referanser:}

1. Britton B, Clover K, Bateman L, et al. Baseline depression predicts malnutrition in head and neck cancer patients undergoing radiotherapy. Support Care Cancer. 2012;20(2):335-42.

\section{Arends J, Baracos V, Bertz H, et al. ESPEN expert} group recommendations for action against cancerrelated malnutrition. Clin Nutr. 2017;36(5):1187-96. 
3. Van Cutsem E, Arends J. The causes and consequences of cancer-associated malnutrition. Eur J Oncol Nurs. 2005;9 Suppl 2:51-63.

4. Mastelaro I, Pupin MP, Ribeiro SM, et al. Longitudinal assessment of nutritional risk in patients under chemo or radiotherapy. Rev Assoc Med Bras (1992). 2016;62(7):659-63.

5. Jain R, Dotan E. Nutrition and Aging: a practicing oncologist's perspective. Curr Oncol Rep. 2017;19(11):71.

6. Andreyev HJ, Norman AR, Oates J, et al. Why do patients with weight loss have a worse outcome when undergoing chemotherapy for gastrointestinal malignancies? Eur J Cancer. 1998;34(4):503-9.

7. Klute KA, Brouwer J, Jhawer M, et al. Chemotherapy dose intensity predicted by baseline nutrition assessment in gastrointestinal malignancies: a multicentre analysis. Eur J Cancer. 2016;63:189-200.

8. Aaldriks AA, van der Geest LG, Giltay EJ, et al. Frailty and malnutrition predictive of mortality risk in older patients with advanced colorectal cancer receiving chemotherapy. J Geriatr Oncol. 2013;4(3):218-26.

9. Yamano T, Yoshimura M, Kobayashi M, et al. Malnutrition in rectal cancer patients receiving preoperative chemoradiotherapy is common and associated with treatment tolerability and anastomotic leakage. Int J Colorectal Dis. 2016;31(4):877-84.

10. Martin L, Senesse P, Gioulbasanis I, et al. Diagnostic criteria for the classification of cancerassociated weight loss. J Clin Oncol. 2015;33(1):90-9.

11. Gioulbasanis I, Martin L, Baracos VE, et al. Nutritional assessment in overweight and obese patients with metastatic cancer: does it make sense? Ann Oncol. 2015;26(1):217-21. 
12. Helsedirektoratet. Nasjonal faglig retningslinje for forebygging og behandling av underernæring. Oslo: Helsedirektoratet; 2010

13. Henriksen C, Gjelstad IM, Nilssen H, et al. A low proportion of malnourished patients receive nutrition treatment - results from nutritionDay. Food Nutr Res. 2017;61(1):1391667.

14. Helsedirektoratet. Pasientsikkerhetsprogrammet: forebygging av underernæring. Oslo: Helsedirektoratet; 2017. Tilgjengelig fra: http://www.pasientsikkerhetsprogrammet.no/omoss/innsatsomr\%C3\%A5der/ern... (nedlastet 25.01.2018).

15. Ravasco P, Monteiro-Grillo I, Camilo M. Individualized nutrition intervention is of major benefit to colorectal cancer patients: long-term followup of a randomized controlled trial of nutritional therapy. Am J Clin Nutr. 2012;96(6):1346-53.

16. Ravasco P, Monteiro-Grillo I, Vidal PM, et al. Dietary counseling improves patient outcomes: a prospective, randomized, controlled trial in colorectal cancer patients undergoing radiotherapy. J Clin Oncol. 2005;23(7):1431-8.

17. Nasjonalt råd for ernæring. Sykdomsrelatert underernæring. Utfordringer, muligheter og anbefalinger. Oslo: Nasjonalt råd for ernæring; 2017. 